\title{
Population dynamics of wheat aphids Rhopalosiphum padi (Linnaeus) and Sitobion avenae (Fabricius) at District Mardan, Khyber Pakhtunkhwa Pakistan
}

\author{
Farman Ullah ${ }^{1,2^{*}}$, Hina Gul ${ }^{1,2}$, Fazal Said ${ }^{2}$, Asad Ali ${ }^{2,3}$, Kaleem Tariq ${ }^{2}$, \\ Maid Zaman ${ }^{4}$ and Dunlun Song ${ }^{1}$ \\ 1. Department of Entomology, China Agricultural University, 100193 Beijing-China \\ 2. Department of Agriculture, Abdul Wali Khan University Mardan, Khyber Pakhtunkhwa-Pakistan \\ 3. State Key Laboratory for Biology of Plant Diseases and Insect Pests, Institute of Plant Protection, Chinese \\ Academy of Agricultural Sciences, Beijing 100193-China \\ 4. Department of Entomology, The University of Haripur, Khyber Pakhtunkhwa-Pakistan \\ *Corresponding author's email: farmanullah@cau.edu.cn \\ Citation \\ Farman Ullah, Hina Gul, Fazal Said, Asad Ali, Kaleem Tariq, Maid Zaman and Dunlun Song. Population dynamics \\ of wheat aphids Rhopalosiphum padi (Linnaeus) and Sitobion avenae (Fabricius) at District Mardan, Khyber \\ Pakhtunkhwa Pakistan. Pure and Applied Biology. Vol. 9, Issue 1, pp27-35. \\ http://dx.doi.org/10.19045/bspab.2020.90004
}

Received: 15/05/2019 Revised: 16/08/2019

Accepted: 26/08/2019

Online First: 20/09/2019

\section{Abstract}

Wheat (Triticum aestivum L.) is one of the major source of food worldwide. However, it suffers from numerous constraints. The aphids, particularly Rhopalosiphum padi (Linnaeus) and Sitobion avenae (Fabricius) species are among the major causes that severly affect wheat production acrossthe globe. To determine the population dynamics of aphids associated with wheat crop in Khyber Pakhtunkhwa, we examined the mean population of both species in the selected areas (Maho Dheri, Sarband, Kandare, Rag Narai and Khazana Dheri) of district Mardan in 2015. The mean population of R. padi and S. avenae per plant were recorded every week by counting the number of aphids on 5 plants picked up randomly from each selected wheat field using the diagonal methods. The results on current study showed that the infestation of both aphid species was started in the $1^{\text {st }}$ week of February ( 05 standard weeks). The densities of aphids per plant increased as the vegetative growth proceeded and was highest till the mid of March $\left(10^{\text {th }}\right.$ and $11^{\text {th }}$ standard week). The declined in aphid populations for both species were started after mid of March and ended in April. The mean population of both aphid species was found low in the $1^{\text {st }}$ week of February $\left(05^{\text {th }}\right.$ standard week) that is probably due to the low temperature. The population density of aphids reached to the its peak in the second week of March due to suitable temperature for aphid infestation.

Keywords: District Mardan; Population dynamics; Rhopalosiphum padi; Sitobion avenae and Wheat

Introduction

Wheat (Triticum aestivum L.) is the primary food source, and use as a staple food contains $13 \%$ protein providing $20 \%$ world food calories. Wheat is used as a food for nearly $40 \%$ of the world's population [1]. The wheat crop is grown on $23 \%$ global cultivated land having utmost importance in international trade for worldwide market [2]. During 201718 the total yield of wheat grown in Pakistan was 26.7 million metric tons, and their consumption was 25.3 million tons [3], while 
755 million metric tons of wheat was produced during 2015-16 worldwide. In Pakistan, Wheat is a major crop and use as a staple food [4]. . The straw and bran are used to feed livestock and also in industries to make several products. Owing to the immense cosumptions, wheat crop is considered to be the $2^{\text {nd }}$ largest crop having $12.5 \%$ contribution in agriculture and $2.6 \%$ to the GDP (Government of Pakistan. 2012). However, various factors affect the quality and quantity of wheat production in Pakistan [5]. Wheat production has been severly affected by so many factors such as immproper seedbeds, low aquality seeds and fertilizers, water shortage and most importantly lack of IPM techniques to mnage insect pests. [6,7]. Aphids attack is one of the most crucial factors for wheat disease and low yield. Aphid is an economically significant insect pest damaging a broad variety of crops, fruits, and vegetable plants [8].

The bird cherry-oat aphid, Rhopalosiphum padi (Linnaeus) and grain aphid, Sitobion avenae (Fabricius) are deleterious insect pests of wheat crops in Pakistan $[9,10]$ and worldwide [11-13]. R. padi and S. avenae are polyphagous sucking insects having worldwide distribution [14] and cause 15\% reduction in the yield of the wheat crop at flowering stage only [15]. These two wheat aphids usually coexist in the wheat crops and cause damage through direct feeding on the sap from shoots and leave, causing distortion, curling, and chlorosis of leaves growth [16, 17]. Besides, these aphid species also act as a vector to transmit numerous fungal and viral diseases that ultimately reducing the yield up to $80 \%[18,19]$. Furthermore, they also act as a vector to transmit barley yellow dwarf virus (BYDV), which cause the indirect destruction of wheat crops [20]. The plants are also damaged indirectly by the excess production of honeydew [21]. The outbreaks of $R$. padi and $S$. avenae lead to severe yield losses in wheat crops [22]. Wheat crops sown in the late season may have high chances of aphids outbreak if the weather remains cool till the end of March [23].

Aphid epidemic could be controlled by sowing cereal crops earlier in the season [24], because low aphid infestation has been documented on early sown wheat crops. Early maturing varieties of wheat can avoid aphids outbreak [25] while infestation increases on late sowing, ultimately cause yield reduction [26]. The seasonal fluctuation in their dynamics are determined through the population growth rate and duration at which the population can grow. Aphids growth rate mainly disturbed by the host plant quality, predators, parasitoids and environmental factors [27]. Diverse factors were encouraged in search for determining the cyclic dynamic of aphids including long-term trends in agriculture practices [21], weather alterations [28], natural enemy profusion, and intraspecific competition [29].

We hypothesized that the annual deviation of aphid populations are driven by the temperature fluctuations. Their profusion is predominantly determined by the duration of aphid population growth. Winter and early spring temperatures thus define stages when aphids attack on cereal crops and the duration available to them prior the onset of plant senescence. In this study, we determine the field population trend of $R$. padi and $S$. avenae in wheat crops at different locations of District Mardan. This constitutes a step towards exploring the diversity of wheat aphid throughout the wheat growing season to elaborate an appropriate control plan against these pests and thus contributing to increase in the production of cereal crops.

\section{Materials and methods}

\section{Field site}

The current experiment was carried out at randomly selected five different locations of District Mardan in Khyber Pakhtunkhwa 
during the wheat grwing growing season i.e. February 2015 - April 2015.

\section{Study design}

Population dynamics of two aphid species $R$. padi and $S$. avenae were estimated following previously described method [30]. Data were recorded at each site by counting aphid population per tiller. At each location, five spots were randomly spaced along a diagonal across the field. The selected spots for samples collecction were not closer than 10 feet from the field edge [30]. The tillers were randomly chosen at each spot and was checked for the $R$. padi and $S$. avenae infestation. Considering the population buildup, which was started in February, therefore data collection was started in the first week (05 standard weeks) of February 2015. Data on mean mean population density of aphid species was recoreded at each location till the crop maturity.

\section{Data analysis}

To assess the mean $( \pm \mathrm{SE})$ number of $R$. padi and $S$. avenae per plant, raw data were subjected to the SPSS 22.0 (IBM Statistics). The statistical differences among data related to the population dynamics of $R$. padi and $S$. avenae were examined using one-way ANOVA followed by Tukey post hoc test ( $P$ $<0.05)$ (IBM, SPSS Statistics). Sigma Plot 12.0 (Systat Software Inc., San Jose, CA) was applied to generate line graphs with error bars.

Results

Population dynamic of $R$. padi in wheat fields

The mean population density of $R$. padi is reported in (Table 1). The estimated mean values shows the increasing trend of aphids population from February till April, as the plant growth proceeded. The highest population growth of $46.67 \pm 0.384,44.17 \pm$ $0.366,52.50 \pm 0.311$ and $33.66 \pm 0.304$ was recorded for $R$. padi in Maho Dheri, Sarband, Rag Narai and Khazana Dheri at the $6^{\text {th }}$ week (SW 10), respectively whereas a mean population of $31.50 \pm 0.311$ of aphids were recorded as highest for Kandare in the $7^{\text {th }}$ week (SW 11) (Table 1).

\section{Population dynamic of $S$. avenae in Wheat fields}

The estimated highest population of $S$. avenae per plant was recorded in the $6^{\text {th }}$ week (SW 10) in Maho Dheri, Rag Narai, Sarband and Khazana Dheri, having $54.83 \pm 0.280$, $48.16 \pm 0.435,43.33 \pm 0.192$ and $42.50 \pm$ 0.311 . The highest population of $S$. avenae in wheat crops at Kandare area was recorded as $36.00 \pm 0.942$ in the $5^{\text {th }}$ week (SW 09). The overall mean population of $S$. avenae in all the selected sites of District Mardan was found high as compared to R. padi (Table 2).

Table 1. Population dynamic (Mean \pm SE) of Rhopalosiphum padi (Linnaeus) in wheat crops from Feb to April 2015 at various locations in District Mardan

\begin{tabular}{|c|c|c|c|c|c|}
\hline $\begin{array}{c}\text { Survey timing } \\
\text { (SW 05-14) }\end{array}$ & Maho Dheri* & Sarband* & Kandare* & Rag Narai* & Khazana Dheri* $^{*}$ \\
\hline Week 01 & $11.00 \pm 0.577 \mathrm{f}$ & $7.00 \pm 0.333 \mathrm{f}$ & $10.50 \pm 0.772 \mathrm{~g}$ & $16.16 \pm 0.280 \mathrm{f}$ & $11.00 \pm 0.235 \mathrm{f}$ \\
\hline Week 02 & $20.66 \pm 0.304 \mathrm{e}$ & $18.67 \pm 1.097 \mathrm{de}$ & $14.83 \pm 0.366 \mathrm{f}$ & $21.00 \pm 0.235 \mathrm{~d}$ & $14.33 \pm 0.561 \mathrm{e}$ \\
\hline Week 03 & $27.50 \pm 0.390 \mathrm{~d}$ & $31.67 \pm 0.192 \mathrm{~b}$ & $24.33 \pm 0.384$ & $21.00 \pm 0.235 \mathrm{~d}$ & $17.16 \pm 0.683 \mathrm{f}$ \\
\hline Week 04 & $34.00 \pm 0.471 \mathrm{c}$ & $17.16 \pm 0.280 \mathrm{e}$ & $17.33 \pm 0.304 \mathrm{e}$ & $35.83 \pm 0.548 \mathrm{c}$ & $21.66 \pm 0.192 \mathrm{c}$ \\
\hline Week 05 & $43.00 \pm 0.527 \mathrm{~b}$ & $26.00 \pm 0.942 \mathrm{c}$ & $26.50 \pm 0.905 \mathrm{bc}$ & $45.33 \pm 0.384 \mathrm{~b}$ & $26.50 \pm 0.204 \mathrm{~b}$ \\
\hline Week 06 & $46.67 \pm 0.384 \mathrm{a}$ & $44.17 \pm 0.366 \mathrm{a}$ & $26.83 \pm 0.280 \mathrm{~b}$ & $52.50 \pm 0.311 \mathrm{a}$ & $33.66 \pm 0.304 \mathrm{a}$ \\
\hline Week 07 & $43.67 \pm 0.304 \mathrm{~b}$ & $31.83 \pm 0.152 \mathrm{~b}$ & $31.50 \pm 0.311 \mathrm{a}$ & $44.00 \pm 0.333 \mathrm{~b}$ & $17.66 \pm 0.384 \mathrm{~d}$ \\
\hline Week 08 & $21.66 \pm 0.304 \mathrm{e}$ & $21.33 \pm 0.384 \mathrm{~d}$ & $21.33 \pm 0.192 \mathrm{~d}$ & $23.00 \pm 0.577 \mathrm{~d}$ & $7.00 \pm 0.333 \mathrm{~g}$ \\
\hline Week 09 & $11.00 \pm 0.577 \mathrm{f}$ & $12.50 \pm 0.204 \mathrm{f}$ & $5.00 \pm 0.471 \mathrm{~h}$ & $18.66 \pm 0.509 \mathrm{e}$ & $3.33 \pm 0.384 \mathrm{~h}$ \\
\hline Week 10 & $3.00 \pm 0.333 \mathrm{~g}$ & $2.16 \pm 0.597 \mathrm{~g}$ & $1.16 \pm 0.152 \mathrm{i}$ & $12.33 \pm 0.384 \mathrm{~g}$ & $0.00 \pm 0.00$ \\
\hline
\end{tabular}

* Within the same column, different letters indicate significant differences at $P<0.05$ level (one-way ANOVA followed by Tukey HSD tests). 
Table 2. Population dynamic (Mean \pm SE) of Sitobion avenae (Fabricius) in wheat crops from Feb to April 2015 at various locations in District Mardan

\begin{tabular}{|c|c|c|c|c|c|}
\hline $\begin{array}{c}\text { Survey timing } \\
\text { (SW 05-14) }\end{array}$ & Maho Dheri* & Sarband* & Kandare* & Rag Narai* & Khazana Dheri* \\
\hline Week 01 & $21.66 \pm 0.192 \mathrm{f}$ & $21.83 \pm 0.152 \mathrm{~d}$ & $19.16 \pm 0.548 \mathrm{e}$ & $21.66 \pm 0.192 \mathrm{e}$ & $22.50 \pm 0.311 \mathrm{e}$ \\
\hline Week 02 & $26.16 \pm 0.548 \mathrm{e}$ & $34.66 \pm 0.509 \mathrm{~b}$ & $23.83 \pm 0.366 \mathrm{~cd}$ & $26.33 \pm 0.838 \mathrm{~d}$ & $26.50 \pm 0.807 \mathrm{~d}$ \\
\hline Week 03 & $37.00 \pm 0.623 \mathrm{c}$ & $27.66 \pm 0.384 \mathrm{c}$ & $25.66 \pm 1.097 \mathrm{bc}$ & $36.83 \pm 0.641 \mathrm{bc}$ & $26.16 \pm 0.796 \mathrm{~d}$ \\
\hline Week 04 & $46.16 \pm 0.597 \mathrm{~b}$ & $35.00 \pm 0.235 \mathrm{~b}$ & $35.33 \pm 0.509 \mathrm{a}$ & $28.00 \pm 0.333 \mathrm{~d}$ & $28.00 \pm 0.333 \mathrm{~cd}$ \\
\hline Week 05 & $54.50 \pm 0.204 \mathrm{a}$ & $46.33 \pm 0.384 \mathrm{a}$ & $36.00 \pm 0.942 \mathrm{a}$ & $39.50 \pm 0.456 \mathrm{~b}$ & $36.16 \pm 1.065 \mathrm{~b}$ \\
\hline Week 06 & $54.83 \pm 0.280 \mathrm{a}$ & $48.16 \pm 0.435 \mathrm{a}$ & $27.83 \pm 0.435 \mathrm{~b}$ & $43.33 \pm 0.192 \mathrm{a}$ & $42.50 \pm 0.311 \mathrm{a}$ \\
\hline Week 07 & $34.33 \pm 0.451 \mathrm{~d}$ & $24.00 \pm 0.235 \mathrm{~d}$ & $22.16 \pm 0.435 \mathrm{de}$ & $34.33 \pm 0.451 \mathrm{c}$ & $31.33 \pm 0.693 \mathrm{c}$ \\
\hline Week 08 & $25.50 \pm 0.311 \mathrm{e}$ & $15.50 \pm 0.772 \mathrm{e}$ & $12.00 \pm 0.408 \mathrm{f}$ & $23.16 \pm 0.435 \mathrm{e}$ & $16.16 \pm 0.723 \mathrm{f}$ \\
\hline Week 09 & $17.66 \pm 0.192 \mathrm{~g}$ & $11.33 \pm 0.192 \mathrm{f}$ & $10.33 \pm 0.192 \mathrm{f}$ & $15.50 \pm 1.099 \mathrm{f}$ & $11.83 \pm 0.641 \mathrm{~g}$ \\
\hline Week 10 & $11.33 \pm 0.192 \mathrm{~h}$ & $4.16 \pm 0.548 \mathrm{~g}$ & $1.50 \pm 0.390 \mathrm{~g}$ & $3.33 \pm 0.384 \mathrm{~g}$ & $2.66 \pm 0.384 \mathrm{~h}$ \\
\hline
\end{tabular}

Population dynamics of $R$. padi and $S$. avenae in Maho Dheri

The highest mean population of $R$. padi were recorded $46.67 \pm 0.384$. In case of $S$. avenae, it was recorded as $54.83 \pm 0.280$ during $6^{\text {th }}$ week (SW 10). The population growth of $S$. avenae declined after week 6 (SW 10), whereas the population of $R$. padi remain high that was later on declined after $7^{\text {th }}$ week (SW 11) (Fig. 1).

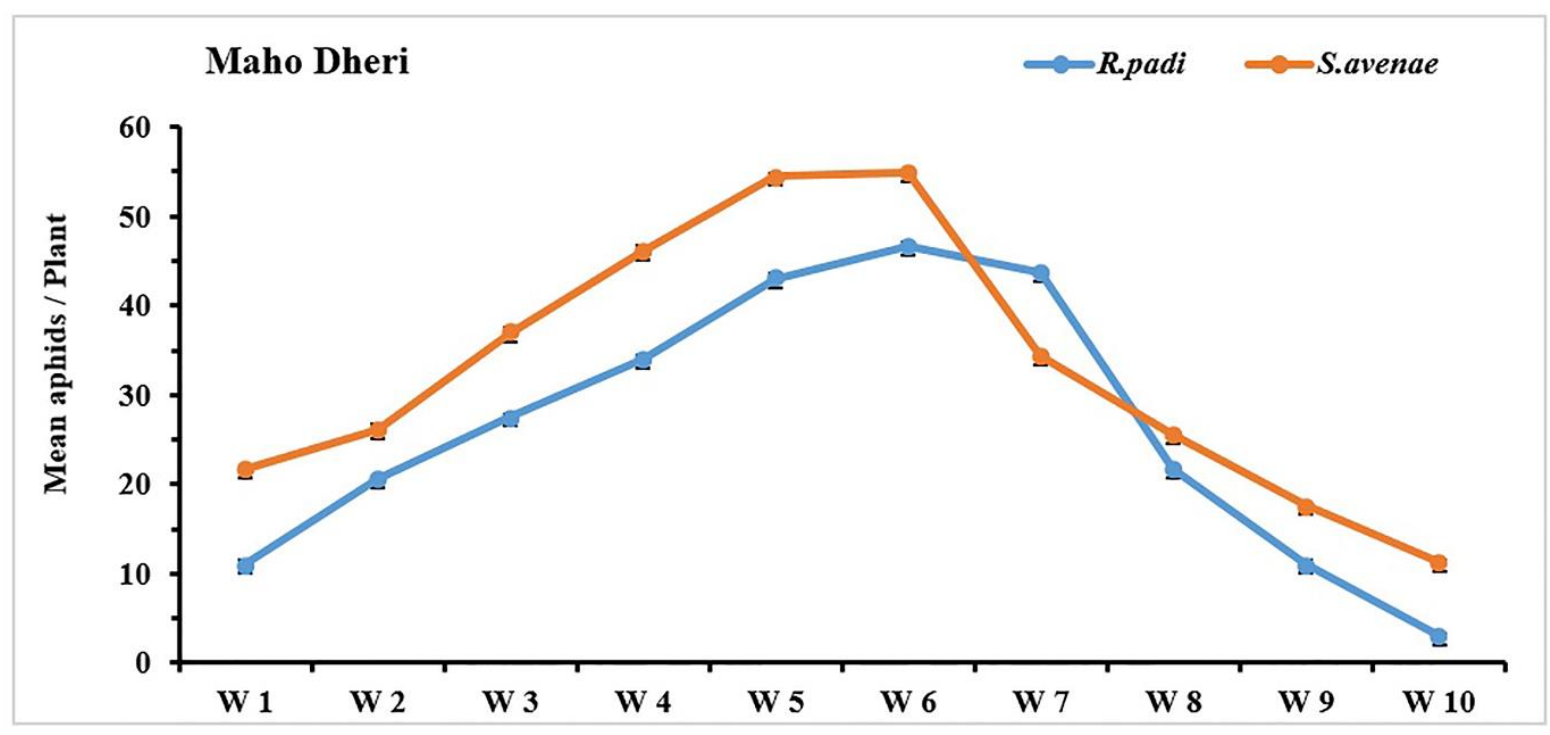

Figure 1. Mean ( \pm SE) population of Rhopalosiphum padi (Linneas) and Sitobion avenae (Fabricius) per plant in wheat crops froms Februray 2015 to April 2015 at Maho Dheri 
Population dynamics of $R$. padi and $S$. avenae in Sarband

In Sarband, the highest mean value for $R$. padi and S. avenae were recorded at week 6 (SW 10) having $44.17 \pm 0.366$ and $48.16 \pm$ 0.435 aphids per plant (Fig. 2). The population of $R$. padi was decreased at week 4 (SW 08) up to $17.16 \pm 0.280$, while $S$. avenae remain high. Population growth of both species was declined after week 6 (SW 10) (Fig. 2).

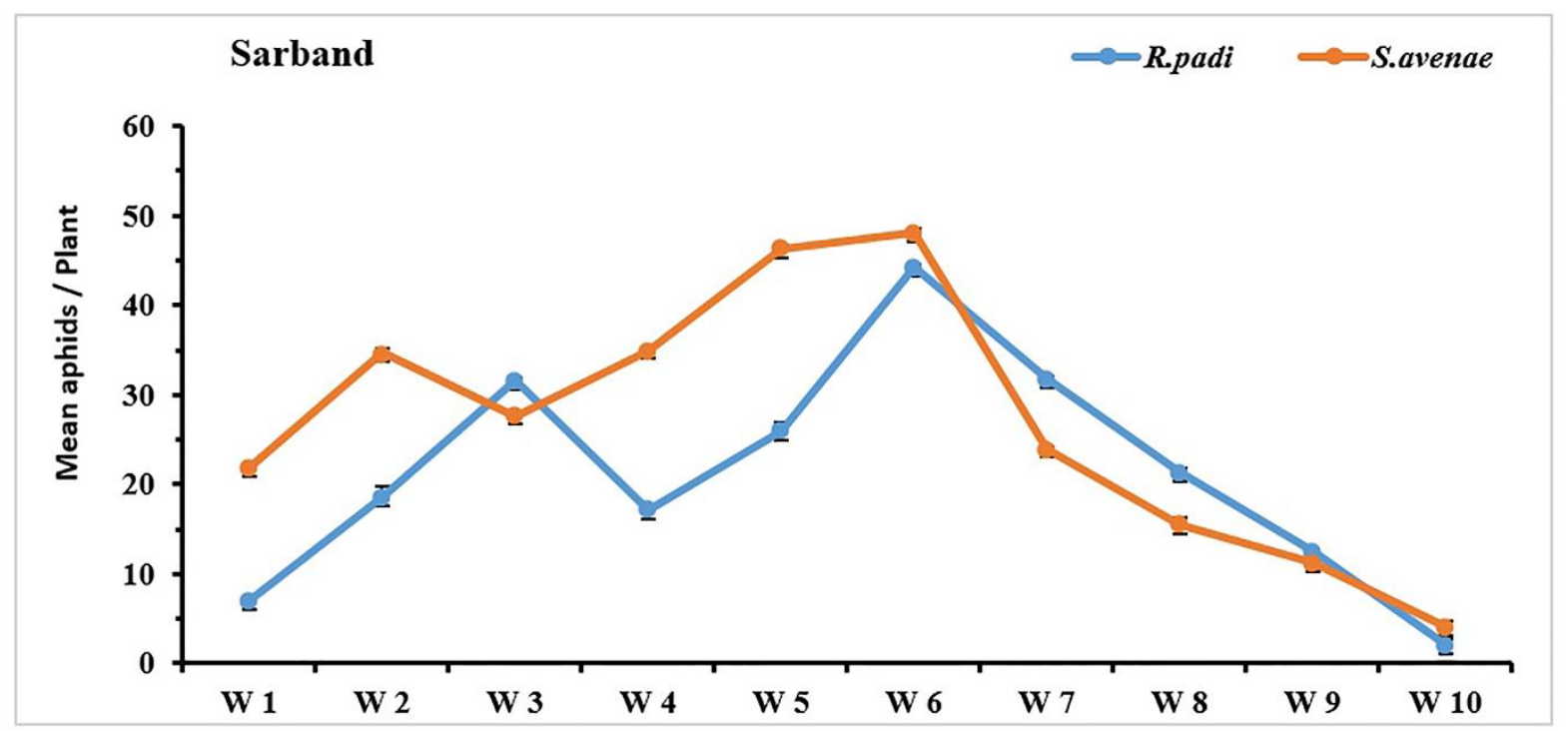

Figure 2. Mean ( $\pm \mathrm{SE})$ population of Rhopalosiphum padi (Linneas) and Sitobion avenae (Fabricius) per plant in wheat crops froms Februray 2015 to April 2015 at Sarband

Population dynamic of $R$. padi and $S$. avenae in Kandare

The mean population of both species (R. padi and $S$. avenae) per plant was observed low as compared to other locations of District Mardan. The highest mean value were 31.50 \pm 0.311 and $36.00 \pm 0.942$ at week 7 (SW 11) and 5 (SW 09) respectively for both species (Fig. 3). The population of S. avenae started to decline after week 5 (SW 09), while population of $R$. padi went down after week 07 (SW 11).

Population dynamic of $R$. padi and $S$. avenae in Rag Narai

The mean highest population of $R$. padi was observed in Rag Narai $(52.50 \pm 0.311)$ as compared to all locations of District Mardan (Table 1, Fig. 4) while mean highest value $(43.33 \pm 0.192)$ for $S$. avenae was also recorded at week 6 (SW 10). Both species populations were declined after week 6 (SW 10) (Fig. 4).

Population dynamic of $R$. padi and $S$. avenae in Khazana Dheri

The highest population growth for $S$. avenae and $R$. padi was $33.66 \pm 0.304$, and $42.50 \pm$ 0.311 observed at week 6 (SW 10) respectively, after which population of aphids was rapidly decreased and ended at week 10 (SW 14) (Fig. 5). 


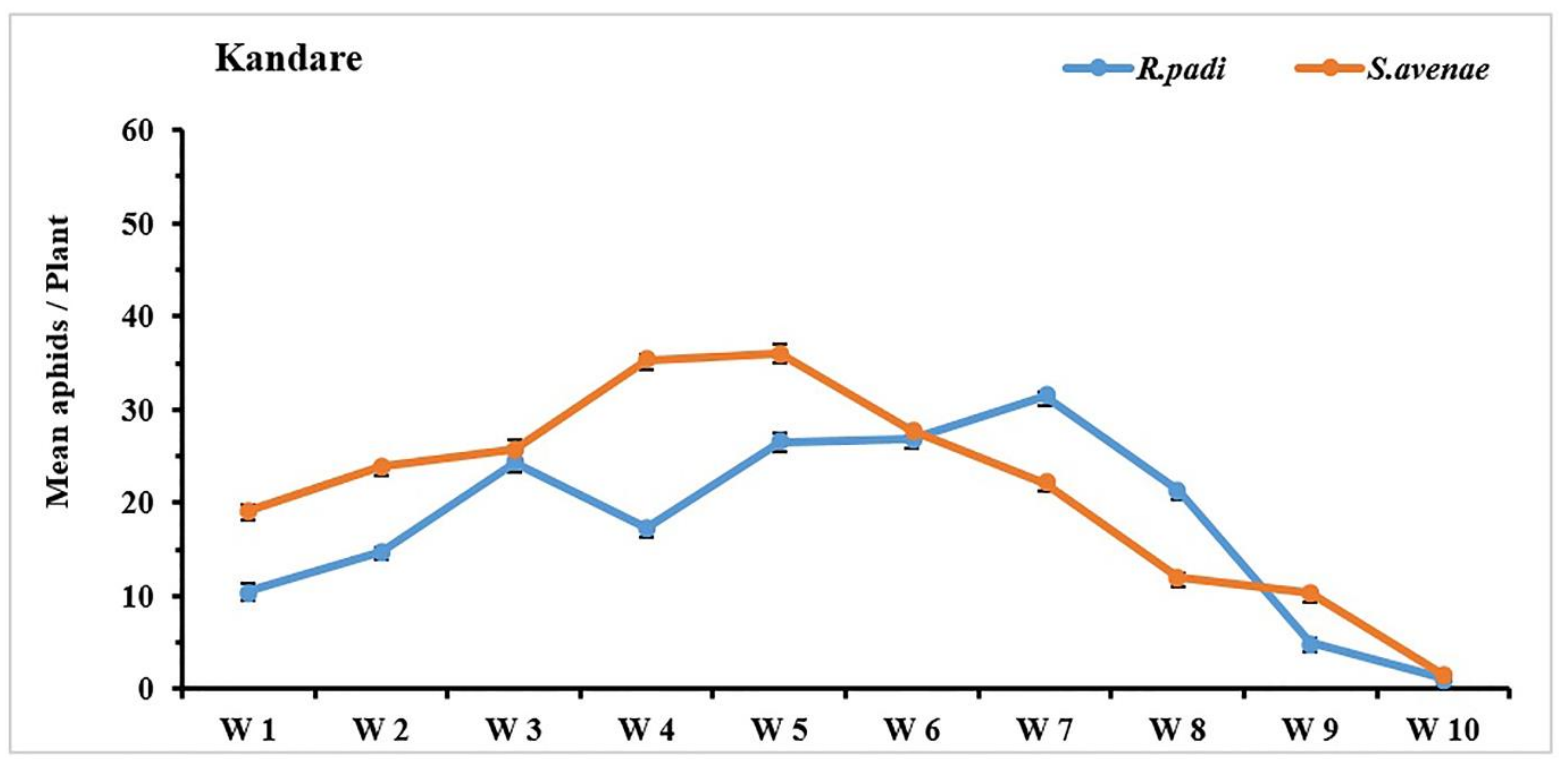

Figure 3. Mean ( \pm SE) population of Rhopalosiphum padi (Linneas) and Sitobion avenae (Fabricius) per plant in wheat crops froms Februray 2015 to April 2015 at Kandare

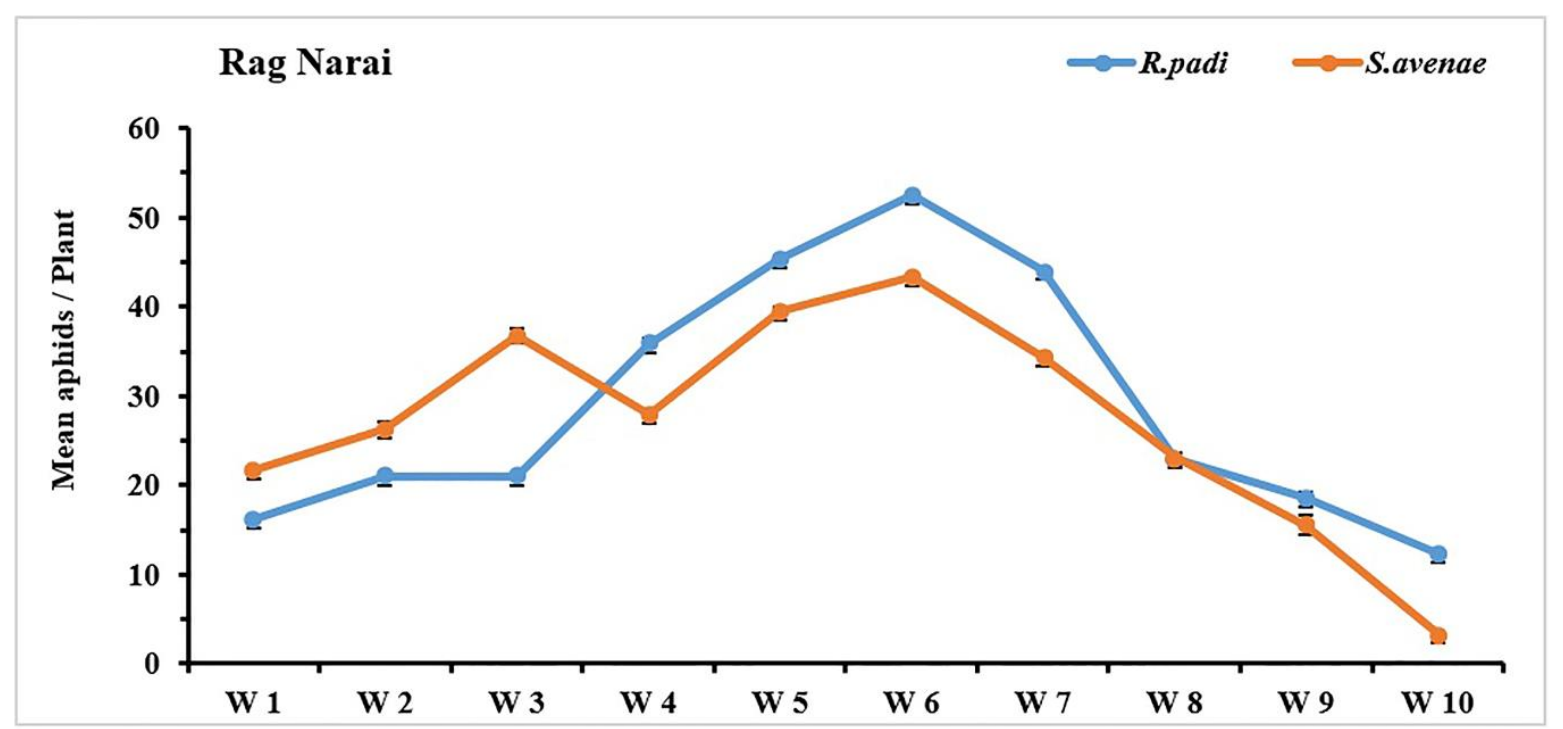

Figure 4. Mean ( \pm SE) population of Rhopalosiphum padi (Linneas) and Sitobion avenae (Fabricius) per plant in wheat crops froms Februray 2015 to April 2015 at Rag Narai 


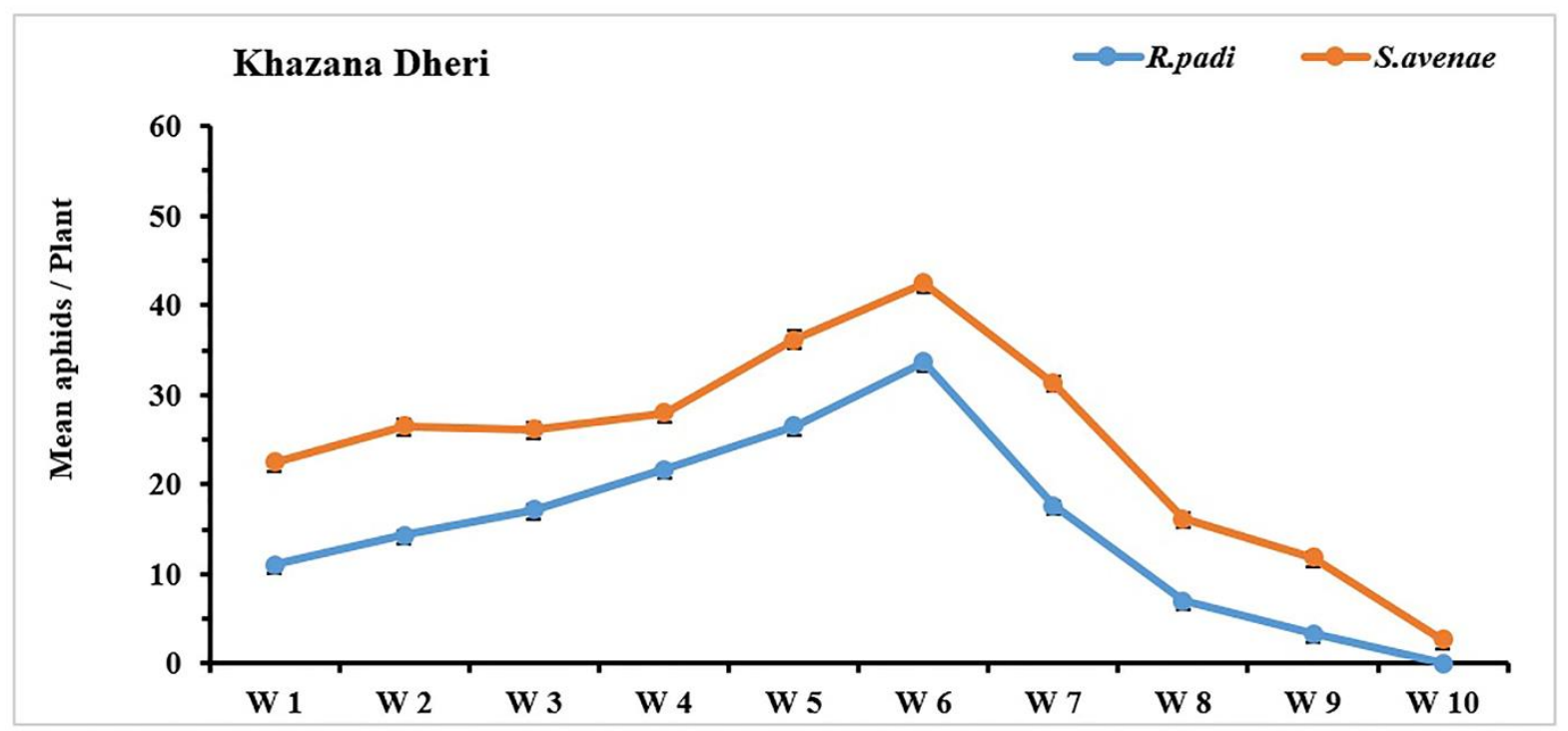

Figure 5. Mean ( \pm SE) population of Rhopalosiphum padi (Linneas) and Sitobion avenae (Fabricius) per plant in wheat crops froms Februray 2015 to April 2015 at Khazana Dheri

\section{Discussion}

The mean population growth of two cereal aphids associated with wheat fields were investigated from February 2015 to April 2015. Our findings are consistent with the previouse study reported that aphid infestation were increased in February and increase with vegetative growth of wheat plant and started decline at the end of March [30].

The mean population of both species of aphid $R$. padi and $S$. avenae was found low in first three weeks (February) at all locations in wheat fields of district Mardan. These results concur with the previous findings showing that aphids population were lower during the end of January or start of February in wheat crops [30]. The highest mean population growth of both aphid species in all the selected sites was found in the end of March. Similar results were documented by $[30,31]$ that the aphid infestation occurred during the $3^{\text {rd }}$ week of March on all wheat varieties.

A gradual increasing trend in population desnity of both species was noticed at vegetative growth stage of wheat crops in all areas. However, some variations occurred in aphid density tiller ${ }^{-1}$, which might be due to the resistance response of wheat varieties against aphids. [8] reported that the aphid population decreased when the temperature reached to the maximum and minimum limit $\left(24^{\circ} \mathrm{C}\right.$ and $\left.9^{\circ} \mathrm{C}\right)$. We found similar results, in which the population growth of both species was lower at the start of February and end of April because in February temperature is less than $10^{\circ} \mathrm{C}$, while in April it is above $24^{\circ} \mathrm{C}$. The population growth of $R$. padi and $S$. avenae was estimated maximum in March when the temperature was in a favorable range of aphid. We also found fluctuation in the mean population for both aphids at different locations, which may be due to various abiotic factors such as temperature, humidity, and rainfall. The rapid increase and decrease in the aphid population were affected by numerous factors [8]. Moreover, it has also been found that alterations in the densities of the aphid population were due to the various physical and biological factors [32]. According to [8,33] temperature have a crucial role in the fluctuation of the aphid population. Similarly, the abundance of aphid 
population was also affected owing to the heavy rainfall [34].

\section{Conclusion}

Based on current study, it is concluded that the population density $R$. padi and $S$. avenae could be controlled by early sowing of wheat crops. Additionally, the indiscriminate use of insecticide influence the population growth of natural enemies, and due to the decrease population of natural enemies in wheat crops, aphids' outbreak occurs and cause severe destruction to the wheat crops.

\section{Authors' contributions}

Conceived and designed the experiments: $F$ Ullah, Performed the experiments: F Ullah, Hina \& A Ali, Analyzed the data: F Said, K Tariq, M Zaman \& D Song, Contributed materials/ analysis/ tools: F Ullah \& D Song, Wrote the paper: F, Ullah \& F Said.

\section{Acknowledgments}

This work was financially supported by the National Key Research and Development Program of China (2016YFD0200500) and the National Natural Science Foundation of China (31272077).

\section{References}

1. Ahmad R \& Shaikh A (2003). Common weeds of wheat and their control. Pak J of Water Resou 7(1): 73-76.

2. Husti I (2006). The main elements of sustainable food chain management. Cereal Res Communications 34(1): 793796.

3. Palmer D. FAO-Food and Agriculture Organization of the United Nations.

4. Ahmad F (2009). Food security in Pakistan. Pak J Agri Sci 46(2): 83-89.

5. Khan AM, Khan AA, Afzal M \& Iqbal MS (2012). Wheat crop yield losses caused by the aphids infestation. $J$ Biofertil Biopestici 3: 122.

6. El-Gizawy NKB (2009). Effect of planting date and fertilizer application on yield of wheat under no till system. World J of Agri Sci 5(6): 777-783.
7. Khattak MK, Riazuddin \& Anayatullah $M$ (2007). Population dynamics of aphids (Aphididae: Homoptera) on different wheat cultivars and response of cultivars to aphids in respect of yield and yield related parameters. Pak J of Zoo 39(2): 109-115.

8. Aheer G, Ali A \& Ahmad M (2008). Abiotic factors effect on population fluctuation of alate aphids in wheat. $J$ Agric Res 46 (4): 367-371.

9. Khan SA, Ullah F, Hussain N, Saljoqi A, Hayat Y \& Sattar S (2006). Distribution pattern of the cereal aphids in the wheat growing areas of the North West Frontier Province (NWFP) of Pakistan. Sarhad J of Agric 22(4): 655.

10. Khan SA \& Ullah F. (2005). Studies on the aphids distribution pattern and their natural enemies in wheat and maize crop. $\mathrm{Ph}$. D. thesis, NWFP Agricultural University, Peshawar.

11. Gaston KJ \& Lawton JH (1988). Patterns in the distribution and abundance of insect populations. Nat 331(6158): 709.

12. Spitzer K, Rejmánek $M$ \& Soldán $T$ (1984). The fecundity and long-term variability in abundance of noctuid moths (Lepidoptera, Noctuidae). Oecologia 62(1): 91-93.

13. Gaston KJ (1988). Patterns in the local and regional dynamics of moth populations. Oikos 49-57.

14. TaheRi S, RazmJou J \& RaSTegaRi N (2010). Fecundity and development rate of the bird cherry-oat. Plant Protection Sci 46(2): 72-78.

15. Oerke E-C (2006). Crop losses to pests. The J of Agric Sci 144(1): 31-43.

16. Khaliq A (2003). Impact of plant phenology and coccinellid predators on the population dynamic of rose aphid Macrosiphum rosaeiformis Das (Aphididae: Homoptera) on rose. Asian J of Plant Sci 2(1): 119-122. 
17. Redfearn A \& Pimm SL (1988). Population variability and polyphagy in herbivorous insect communities. Ecolog Monographs 58(1): 39-55.

18. Rossing W, Daamen R \& Jansen M (1994). Uncertainty analysis applied to supervised control of aphids and brown rust in winter wheat. Part 2. Relative importance of different components of uncertainty. Agric Sys 44: 449-460.

19. Goggin FL (2007). Plant-aphid interactions: molecular and ecological perspectives. Current Opinion in Plant Biol 10(4): 399-408.

20. Honek A \& Martinková Z (2005). Long term changes in abundance of Coccinella septempunctata (Coleoptera: Coccinellidae) in the Czech Republic. Eur J of Entomol 102(3): 443.

21. Brault V, Herrbach É \& Reinbold C (2007). Electron microscopy studies on luteovirid transmission by aphids. Micron 38(3): 302-312.

22. Blackman R \& Eastop V (1986). Aphids on the world's crops: An identification and information guide: John Wiley and Sons pp 466.

23. Bhambhro S (2002). Threat of aphids to wheat crop. DAWN-Business, The Internet Edition.https://www.dawn.com/

24. Acreman $\mathrm{T} \&$ Dixon A (1985). Developmental patterns in wheat and resistance to cereal aphids. Crop Protection 4(3): 322-328.

25. Barabas L \& Benovsky J (1985). The effect of winter wheat cultivars on the intensity of occurrence of the grain aphid (Sitobion avenae F). Ochrona Rostlin 21(3): 195-199.

26. Aheer G, Ulfat M, Jawad K \& Ali A (1993). Effect of sowing dates on aphids and grain yield in wheat. J Agric Res 31(1): 75-79.
27. Stark JD \& Banks JE (2003). Populationlevel effects of pesticides and other toxicants on arthropods. Annu Rev Entomol 48(1): 505-519.

28. Biondi A, Zappalà L, Stark JD \& Desneux N (2013). Do biopesticides affect the demographic traits of a parasitoid wasp and its biocontrol services through sublethal effects? PLoS ONE 8(9): e76548.

29. Fogel MN, Schneider MI, Desneux N, González B \& Ronco AE (2013). Impact of the neonicotinoid acetamiprid on immature stages of the predator Eriopis connexa (Coleoptera: Coccinellidae). Ecotoxicol 22(6): 1063-1071.

30. Ali A \& Ali H 2015. Population dynamics of cereal aphids in wheat crop at District Swabi. Intl J of Agric and Environ Res 1(1): 25-31.

31. Rustamani M, Sheikh S, Memon N, Leghari M \& Dhaunroo M (1999). Impact of wheat plant phenology on the development of greenbug, Schizaphis graminum (RONDANI). Pak $J$ of Zool 31(3): 245-248.

32. Naeem S, Håkansson K, Lawton JH, Crawley M \& Thompson LJ (1996). Biodiversity and plant productivity in a model assemblage of plant species. Oikos 259-264.

33. Aslam M, Razaq M, Akhter W, Faheem M \& Ahmad F. (2005). Effect of sowing date of wheat on aphid (Schizaphis gramium RONDANI) population. Pak Entomol 27(1): 79-82.

34. Srivastava A, Greppin H \& Strasser RJ (1995). The steady state chlorophyll a fluorescence exhibits in vivo an optimum as a function of light intensity which reflects the physiological state of the plant. Plant and Cell Physiol 36(5): 839-848. 